\title{
CUSTOMERS' ASSESSMENT ON E-BANKING SERVICE QUALITY IN BANGLADESH: CHALLENGES AND STRATEGIES
}

\author{
Dhiman Barua \\ Assistant Professor \\ Faculty of Business Administration \\ BGC Trust University Bangladesh \\ M.Phil Researcher \\ Department of Finance, Jagannath University, Bangladesh \\ E-mail: dhiman@bgctub.ac.bd \\ S. M. Akber \\ Lecturer \\ Department of Business Administration \\ Ranada Prasad Shaha University, Bangladesh \\ M.Phil Researcher \\ Department of Finance, Jagannath University, Bangladesh \\ E-mail: akber@rpsu.edu.bd \\ iD https://orcid.org/0000-0002-0267-3626
}

Received: October 04, 2021 Accepted: October 31, 2021 Online Published: November 26, 2021

DOI: $10.46281 / a m f b r . v 6 i 1.1456$

URL: https://doi.org/10.46281/amfbr.v6i1.1456

\begin{abstract}
This paper attempts to investigate to understand customers' evaluation regarding service quality of e-banking in Bangladesh. It also examines the major challenges and required strategies for promoting e-banking. To conduct the study, a total number of 205 respondents were taken as sample from Chittagong region by using simple judgmental sampling technique. A face-to-face interview method was followed by using a structured questionnaire to collect the data. Five points Likert scale was used to examine the customers' evaluation on the service quality and through statistical measures it analyze the problem. Garret's ranking technique was applied to rank the qualitative data for analyzing challenges and required strategies of e-banking. The study reveals that from the customers' assessment, e-banking saves time and hazard, facilitates quick and easier access to information, speedy transaction, receiving service easily, ensures accuracy, effectiveness and security, provides versatile service, anytime, anywhere banking facility. The study also found that technological disturbance, insufficient infrastructure, unavailability of service in rural areas, high service charge are the major challenges of $e$ banking service in Bangladesh. The customers suggests to develop infrastructure, upgrade
\end{abstract}


technology, increase security measure, enhance promotion for developing customers' awareness, introduce innovative initiative of Bangladesh bank, extend service across the country etc.

Keywords: E-Banking, Service Quality, Customers’ Assessment.

JEL Classification Codes: G21, L15.

\section{INTRODUCTION}

There has been a significant change in the banking operation for the last few decades across the world due to quick change of technology. Banks are receiving updated technology for rendering new and better service and meeting competition in the market. E-banking is one of the methods of banking that rely on the best use of technology.

The improvement of information technology and the accessibility of the internet have made it possible that one can take banking service from a remote area without stepping into a physical financial structure (Bruene, 2002). E-banking provides different information to customer through computer, telephone or mobile phone (Daniel, 1999). It allows customers to perform different transactions including account transfers, balance inquiries, online loan and credit card applications, bill payments staying away from banks. Comparing with traditional banking system, e-banking facilitates customers to receive 24-hour services, transactions at low cost, more secured transactions, higher volume of transactions at minimum time, more accurate transaction (Nasri, 2011).

In Bangladesh, e-banking service is expanding rapidly as the people intension to adopt new technology is growing day by day. It has got massive prospective to open up new window of opportunity to the existing banks and financial institutions in our country. The initiative of Bangladesh Bank encourages bank financial institutions to promote e-banking. The e-banking service of foreign and local private commercial bank is better in consideration with state-owned commercial banks (Huda \& Chowdhury, 2017). Banks are trying to render new and updated ebanking service to attract and retain customers. Having huge demand from retail customers and business community e-banking is still at a budding state due to some constraints like inadequacy of reliable and secure information infrastructure, poor network connectivity, high internet charge, lack of IT literacy of customers, insufficient legal and regulatory framework, huge investment requirement for adopting new technology etc. (Sadekin \& Shaikh, 2016). Bangladesh bank needs to take several innovative initiatives to boost e-banking service across the country. Commercial banks should also come forward to introduce new technology in their banking operation for ensuring customers' satisfaction and meeting global challenge.

There were very few studies conducted on e-banking practices in Bangladesh particularly no comprehensive study has yet been conducted regarding customers' assessment. Besides, the challenges of adopting e-banking along with the required strategies to be followed were not covered in the previous studies. The focus of this study is to fulfill the gap.

\section{LITERATURE REVIEW}

E-banking is the latest development in financial services by bank financial institutions through taking the benefits of the Internet's power and access to cope with the accelerating pace of changing global business (Mia et al., 2007). The term "e-banking" refers to a banking system in which customers are able to conduct their banking operation electronically without visiting a bank branch (Simpson, 2002). Burr (1996) defines e-banking as a banking system that connect 
the bank and customer digitally for preparing, managing and controlling financial transactions. It is not a product or service of a bank; rather it indicates the way of managing banking operation.

E-banking offers better banking experience to customers and provide new and updated banking services for greater satisfaction. E-banking ensures convenience and flexibility in banking transaction. It also provides transaction related benefits like easy transfer, quick transaction, saves cost and time (Ahmed et al., 2012). Sadekin and Shaikh (2016) studied on effect of e-banking on banking sector of Bangladesh and observed that e-banking requires less human resource, reduces carrying cash, provides shopping and other facilities by using cards, demands less documents in banking operation. E-banking services allow banks to reduce infrastructure cost. It is believed that the e-banking increases the profitability of banks through reducing the cost and provides additional benefits to customers as well (Halperin, 2001). Howcroft and Durkin (2003) decorated that online banking technology assist to build a good relationship between bank and customers. They revealed that successful adoption of modern technology in banking sector can increase average productivity, efficiency and profitability of banks. Al-Amin and Rahman (2010) stated that better IT infrastructure, internal network and country domain are the major issues for the promotion of online banking in Bangladesh. Sadekin et al. (2019) found that customers trust on e-banking depends on security system, customers awareness, academic qualification, authentication of e-transaction, service quality of banks, bankers behavior etc. Liao and Cheung (2002) revealed that customers expectation regarding accuracy, security, quick transaction, flexibility, user friendliness, convenience were the most important quality attributes that perceived usefulness of internet based e-retail banking.

Banking sector in Bangladesh have been facing a number of challenges such as lack of technological skill of both bankers and customers, absence of centralized country wide data based system, high cost of adoption of new technology in banking system, absence of integrated e-banking service plan among banks, lack of proper initiatives of Bangladesh Bank, different software for different banks, legal bindings and inappropriate policy frameworks (Uddin et al., 2016). Baten and Kamil (2010) argued that Bangladeshi customers of do not have enough knowledge of e-banking which restrict to extend e-banking in Bangladesh. Sadekin and Shaikh (2016) observed that customers feel insecurity from hijacker to withdraw and deposit money from ATM booths and it risks; market risks; and liquidity risks. Rahman (2008) observed that online banking in Bangladesh faces several constraints like lack of safe telecommunication infrastructure, poor network facility, lack of skilled human resource and training facilities, absence of supportive policies, guidelines, rules and regulations relating to e-transactions and the like. Alam et al. (2007) assessed the development and prospects of Internet Banking in Bangladesh and observed that lack of necessary infrastructure is the key challenge for adopting internet based banking system in the country. They also found that nationalized commercial banks still failed to implement modern internet banking system due to lack of proper initiative from Bangladesh Bank. Mattila and Mattila (2005) also claimed that security system is the main barrier to adopt e-banking and introduce new technology in the banking operation. They also observed some other social and psychological factors influence customers to receive digital banking system. Akber (2020) made a research on comparing the performance of traditional private commercial banks and Islamic banks in Bangladesh. He used a sample of five traditional commercial private banks and five Islamic banks. He came with an outcome that private commercial private banks perform better in providing e banking services compared Islamic banks in Bangladesh. 
Uddin et al. (2016) recommended to increase promotion through advertisement, reduce charge on e-banking products or services, improve security counter measures, introducing new technology in the banking operation, and provide training to employees by the commercial banks. Khanam and Alam (2018) studied on factors affecting the adoption of internet banking and stated that banking sector of Bangladesh should focus on improving ICT infrastructure, strengthening security system, improving customer awareness, developing long term strategic plan to promote e-banking system. They also mentioned the participation of government to improve legal framework and policy guideline. Nelubiri and Sinti (2006) argued that banks should different initiatives for increasing awareness of customers and building positive perception and mindset to accept internet technology in conducting banking activities.

The objectives of the study are:

\section{OBJECTIVES OF THE STUDY}

i) To present the customers' evaluation on the e-banking service quality.

ii) To identify the major challenges and required strategies for promoting e-banking from customers' perspective.

\section{RESEARCH METHODOLOGY}

This is particularly a descriptive study based on collected data from primary sources. Data were collected from a sample of 205 respondents and a simple judgmental sampling technique was used to detect the respondents. A structured questionnaire was developed and a face to face interview method was followed to collect the data. The questionnaire contained two parts. Part I contained customers' evaluation on the e-banking service quality. Five points Likert Scale (from 1- strongly disagree to 5- strongly agree) was used to assess the perceptions. In part II, major challenges and required strategies for promoting e-banking were assessed by using Garret table rating scale to rank qualitative data in a higher priority entitling 1 to lowest priority.

Customers' evaluation on e-banking service quality were analyzed in a descriptive, multidimensional manner using SPSS 16.0 software and frequencies, percentage, mean, standard deviation were computed to analyze the problem. To analyze the challenges and strategies of ebanking, Garret's ranking technique (Masukujjamam et al., 2016) was used. It was calculated as percentage score and the scale value was obtained by employing Scale Conversion Table given by Henry Garrett. The percentage score was calculated as follows

Percentage score $=100($ Rij-0.5) $/$ Nij)

Where $\mathrm{Rij}$ is the rank given for $\mathrm{i}^{\text {th }}$ item $\mathrm{jth}$ individual

$\mathrm{Nij}$ is the number of items ranked by jth individual.

Using Scale Conversion Table of Henry Garrett, the percentage score was obtained for all ranks. The score value (fx) was calculated for each factor by multiplying number of respondents (f) with respective scale value $(\mathrm{x})$. The total scores were computed by adding the score value (fx) of each rank for every factor. The mean score was then calculated to know the order of perception given by the respondents.

\section{DATA ANALYSIS}

\section{Customers' Assessment on E-Banking Service Quality}

Saving time and hazard: Table 1 shows the customers' assessment on 'e-banking saves time and hazard". In response to the statement, majority of the respondents $(52.2 \%)$ agreed on the 
statement and a good percentage of respondents (22.4\%) strongly agreed on the issue. The mean of the responses is also high (3.8878). Standard deviation is relatively low (0.88123) which indicates a greater consistency in the response to the statement.

Table 1. Savings time and hazard

\begin{tabular}{|c|c|c|c|}
\hline Responses & Frequency & Percent & \\
\hline Strongly disagree -1 & 6 & 2.9 & \\
\hline Disagree -2 & 5 & 2.4 & Mean 3.8878 \\
\hline Neutral - 3 & 41 & 20.0 & $\begin{array}{c}\text { Std. Deviation } \\
.88123\end{array}$ \\
\hline Agree - 4 & 107 & 52.2 & \\
\hline Strongly agree - 5 & 46 & 22.4 & \\
\hline Total & 205 & 100.0 & \\
\hline
\end{tabular}

Source: Field survey

Quick and Easier Access to Information: Customers' assessment on "e-banking facilitates quick and easier access to information of clients" is shown in table 2. Highest 44.4 percent of the respondents agreed on the statement followed by 24.9 percent felt neutral. The mean of the responses is not much high (3.4829) and the value of standard deviation (1.08734) indicates comparatively less consistency in the response.

Table 2. Quick and easier access to information

\begin{tabular}{|c|c|c|c|}
\hline Responses & Frequency & Percent & \\
\hline Strongly disagree -1 & 16 & 7.8 & \\
\hline Disagree - 2 & 18 & 8.8 & Mean 3.4829 \\
\hline Neutral -3 & 51 & 24.9 & $\begin{array}{c}\text { Std. Deviation } \\
1.08734\end{array}$ \\
\hline Agree -4 & 91 & 44.4 & \\
\hline Strongly agree - 5 & 29 & 14.1 & \\
\hline Total & 205 & 100.0 & \\
\hline
\end{tabular}

Source: Field survey

Versatile service facility: The response of the Customers' assessment on "e-banking offers versatile service facility" is shown in table 3. Majority of the respondents (45.4 percent) support the issue whereas a high portion (28.8 percent) of respondents felt neutral. The average response (3.4439) on the statement is not much high.

Table 3. Versatile service facility

\begin{tabular}{|c|c|c|c|}
\hline Responses & Frequency & Percent & \\
\hline Strongly disagree -1 & 6 & 2.9 & \\
\hline
\end{tabular}




\begin{tabular}{|c|c|c|c|}
\hline Disagree -2 & 28 & 13.7 & Mean 3.4439 \\
\hline Neutral -3 & 59 & 28.8 & Std. Deviation .94091 \\
\hline Agree -4 & 93 & 45.4 & \\
\hline Strongly agree -5 & 19 & 9.3 & \\
\hline Total & 205 & 100.0 & \\
\hline
\end{tabular}

Source: Field survey

Speedy transaction: Customers' evaluation on "e-banking facilitates speedy transaction" is shown in table 2. On the issue, 50.02 percent respondents agreed on the statement and 28.3 percent highly strongly agreed on it. The mean score is also high (4.0439) which represent customers' confidence on the facility.

Table 4. Speedy transaction

\begin{tabular}{|c|c|c|c|}
\hline Responses & Frequency & Percent & \\
\hline Strongly disagree -1 & 0 & 0.0 & \\
\hline Disagree -2 & 5 & 2.4 & Mean 4.0439 \\
\hline Neutral -3 & 39 & 19.0 & Std. Deviation .75604 \\
\hline Agree -4 & 103 & 50.2 & \\
\hline Strongly agree -5 & 58 & 28.3 & \\
\hline Total & 205 & 100.0 & \\
\hline
\end{tabular}

Source: Field survey

Security system: Table 5 shows the customers' evaluation on "security system of e-banking is high." In response to the statement, 40 percent respondents felt secured on e-banking system followed by 24.9 percent felt neutral on the statement. A good number of respondents (18.5 percent) disagreed on the security system of online banking. The mean of the response is comparatively low (3.1756).

Table 5. Security system

\begin{tabular}{|c|c|c|c|}
\hline Responses & Frequency & Percent & \\
\hline Strongly disagree - 1 & 19 & 9.3 & \\
\hline Disagree - 2 & 38 & 18.5 & Mean 3.1756 \\
\hline Neutral - 3 & 51 & 24.9 & Std. Deviation 1.08734 \\
\hline Agree - 4 & 82 & 40.0 & \\
\hline Strongly agree - 5 & 15 & 7.3 & \\
\hline Total & 205 & 100.0 & \\
\hline
\end{tabular}

Source: Field survey

Easy to receive banking service: Table 6 shows the customers' perception on "e-banking services are easy to receive". In response to the statement, highest 45.4 percent of the respondents agreed on the statement followed by 23.9 percent felt neutral. The mean of the 
responses is also high (3.8878). Standard deviation is relatively low (0.88123) which indicates a greater consistency in the response to the statement.

Table 6. Easy to receive banking service

\begin{tabular}{|c|c|c|c|}
\hline Responses & Frequency & Percent & \\
\hline Strongly disagree -1 & 11 & 5.4 & \\
\hline Disagree -2 & 27 & 13.2 & Mean 3.4585 \\
\hline Neutral -3 & 49 & 23.9 & $\begin{array}{c}\text { Std. Deviation } \\
1.04059\end{array}$ \\
\hline Agree -4 & 93 & 45.4 & \\
\hline Strongly agree -5 & 25 & 12.2 & \\
\hline Total & 205 & 100.0 & \\
\hline
\end{tabular}

Source: Field survey

Anytime, anywhere banking facility: Table 7 shows the customers' assessment on "e-banking offers anytime, anywhere banking facility". In response to the statement, majority of the respondents $(45.4 \%)$ agreed on the statement and a high percentage of respondents $(22.4 \%)$ felt neutral on the issue though a good percentage of respondents disagreed (13.2\%) on it. The mean of the responses is also high (3.9659).

Table 7. Anytime, anywhere banking facility

\begin{tabular}{|c|c|c|c|}
\hline Responses & Frequency & Percent & \\
\hline Strongly disagree -1 & 3 & 1.5 & \\
\hline Disagree -2 & 16 & 7.8 & Mean 3.9659 \\
\hline Neutral -3 & 29 & 14.1 & Std. Deviation .94651 \\
\hline Agree -4 & 94 & 45.9 & \\
\hline Strongly agree -5 & 63 & 30.7 & \\
\hline Total & 205 & 100.0 & \\
\hline
\end{tabular}

Source: Field survey

Accuracy and effectiveness of banking system: Customers' perception on "e-banking provides accurate and effective banking system" is shown in table 8 . Highest 42 percent of the respondents agreed on the statement followed by 27.3 percent felt neutral. Besides, 18 percent respondents strongly agreed on it. The man score is average (3.6049) but standard deviation is little bit higher (1.02660).

Table 8. Accuracy and effectiveness of banking system

\begin{tabular}{|c|c|c|c|}
\hline Responses & Frequency & Percent & \\
\hline Strongly disagree -1 & 10 & 4.9 & \\
\hline Disagree -2 & 16 & 7.8 & Mean 3.6049 \\
\hline Neutral -3 & 56 & 27.3 & Std. Deviation 1.02660 \\
\hline
\end{tabular}




\begin{tabular}{|c|c|c|c|}
\hline Agree -4 & 86 & 42.0 & \\
\hline Strongly agree - 5 & 37 & 18.0 & \\
\hline Total & 205 & 100.0 & \\
\hline
\end{tabular}

Source: Field survey

\section{Challenges of E-banking}

E-banking facilitates customers to access their accounts, obtain information, and transfer money between different accounts and making payment via online channel. Customers can enjoy anytime, anywhere banking facilities and receive wide range of service across the country. Despite the different attractive issues, adoption of e-banking faces a number of challenges in Bangladesh. The challenges of e-banking from the realization of customers are shown in table 9 .

Table 9. Challenges of e-banking

\begin{tabular}{|c|c|c|c|c|c|c|c|c|c|c|c|c|}
\hline \multicolumn{2}{|c|}{$\begin{array}{c}\text { Challenges of } \\
\text { e- banking }\end{array}$} & 1 & 2 & 3 & 4 & 5 & 6 & 7 & Total & $\begin{array}{c}\text { Total } \\
\text { Garrett } \\
\text { Score }\end{array}$ & $\begin{array}{l}\text { Mean } \\
\text { Score }\end{array}$ & Rank \\
\hline \multirow{2}{*}{$\begin{array}{l}\text { System } \\
\text { complexity }\end{array}$} & $\mathrm{f}$ & 18 & 36 & 13 & 40 & 42 & 27 & 29 & \multirow{2}{*}{205} & \multirow{2}{*}{9872} & \multirow{2}{*}{48.16} & \multirow{2}{*}{5} \\
\hline & $f x$ & 1422 & 2376 & 741 & 2000 & 1806 & 918 & 609 & & & & \\
\hline \multirow{2}{*}{$\begin{array}{l}\text { High service } \\
\text { charge }\end{array}$} & $\mathrm{f}$ & 27 & 20 & 38 & 35 & 45 & 29 & 11 & \multirow{2}{*}{205} & \multirow{2}{*}{10521} & \multirow{2}{*}{51.32} & \multirow{2}{*}{4} \\
\hline & $f x$ & 2133 & 1320 & 2166 & 1750 & 1935 & 986 & 231 & & & & \\
\hline \multirow{2}{*}{$\begin{array}{l}\text { Insufficient } \\
\text { infrastructure }\end{array}$} & $\mathrm{f}$ & 39 & 48 & 26 & 27 & 15 & 29 & 21 & \multirow{2}{*}{205} & \multirow{2}{*}{11153} & \multirow{2}{*}{54.40} & \multirow{2}{*}{2} \\
\hline & $f x$ & 3081 & 3168 & 1482 & 1350 & 645 & 986 & 441 & & & & \\
\hline \multirow{2}{*}{$\begin{array}{l}\text { Lack of } \\
\text { knowledge of } \\
\text { customers }\end{array}$} & $\mathrm{f}$ & 13 & 29 & 37 & 31 & 13 & 36 & 46 & \multirow{2}{*}{205} & \multirow{2}{*}{9349} & \multirow{2}{*}{45.60} & \multirow{2}{*}{6} \\
\hline & $f x$ & 1027 & 1914 & 2109 & 1550 & 559 & 1224 & 966 & & & & \\
\hline \multirow{2}{*}{$\begin{array}{l}\text { Technological } \\
\text { disturbance }\end{array}$} & $\mathrm{f}$ & 44 & 38 & 31 & 29 & 20 & 20 & 23 & \multirow{2}{*}{205} & \multirow{2}{*}{11224} & \multirow{2}{*}{54.75} & \multirow{2}{*}{1} \\
\hline & fx & 3476 & 2508 & 1767 & 1450 & 860 & 680 & 483 & & & & \\
\hline \multirow{2}{*}{$\begin{array}{l}\text { Unavailability } \\
\text { of service in } \\
\text { rural areas }\end{array}$} & $\mathrm{f}$ & 40 & 24 & 32 & 27 & 28 & 30 & 24 & \multirow{2}{*}{205} & \multirow{2}{*}{10652} & \multirow{2}{*}{51.96} & \multirow{2}{*}{3} \\
\hline & fx & 3160 & 1584 & 1824 & 1350 & 1204 & 1020 & 504 & & & & \\
\hline \multirow{3}{*}{$\begin{array}{l}\text { High } \\
\text { investment in } \\
\text { automation \& } \\
\text { maintenance }\end{array}$} & $\mathrm{f}$ & 24 & 10 & 28 & 16 & 42 & 34 & 51 & \multirow{2}{*}{205} & \multirow{2}{*}{8985} & \multirow{2}{*}{43.83} & \\
\hline & fx & 1896 & 660 & 1596 & 800 & 1806 & 1156 & 1071 & & & & t \\
\hline & & 79 & 66 & 57 & 50 & 43 & 34 & 21 & & & & \\
\hline
\end{tabular}

Source: Field survey 
Customers perceived the technological disturbance as the first challenge (mean score 54.75) to implement e-banking system. Insufficient infrastructure (mean value 54.40) is placed at the second position in the table followed by unavailability of service in rural areas (mean value 51.96). Slow response of internet connection and sometimes internet connection break down which make interrupt the e-banking system. E-banking system in Bangladesh is still suffering from lack of updated and innovative IT resources and power backup for running the operation smoothly. High charge of services and different hidden cost in addition with complexity in operational system discourage customers to accept online banking. Thus customers considered high service charge and system complexity as the fourth and fifth challenge respectively. Customers also realized that their lack of knowledge and high investment in automation \& maintenance are least important challenges to implement e-banking system.

\section{Strategies required to improve e-banking:}

To meet the challenges and provide better banking service banks need to develop strategic plan for promoting e-banking system. The required strategies from the assessment of customers are showed in table 10.

Table 10. Strategies

\begin{tabular}{|c|c|c|c|c|c|c|c|c|c|c|c|c|c|}
\hline \multicolumn{2}{|l|}{ Strategies } & \multirow{2}{*}{$\begin{array}{c}1 \\
\\
24\end{array}$} & \multirow{2}{*}{$\begin{array}{l}2 \\
29\end{array}$} & \multirow{2}{*}{$\begin{array}{c}3 \\
\\
42\end{array}$} & \multirow{2}{*}{$\begin{array}{l}4 \\
\\
33\end{array}$} & \multirow{2}{*}{$\begin{array}{l}5 \\
\\
20\end{array}$} & \multirow{2}{*}{$\begin{array}{c}6 \\
19\end{array}$} & \multirow[b]{2}{*}{15} & \multirow{2}{*}{$\begin{array}{c}8 \\
\\
23\end{array}$} & \multirow{3}{*}{$\begin{array}{c}\text { Total } \\
205\end{array}$} & \multirow{3}{*}{$\begin{array}{c}\text { Total } \\
\text { Garrett } \\
\text { Score } \\
10787\end{array}$} & \multirow{3}{*}{$\begin{array}{l}\text { Mean } \\
\text { Score } \\
52.62\end{array}$} & \multirow{3}{*}{$\begin{array}{c}\text { Rank } \\
\\
4\end{array}$} \\
\hline Increasing & $\mathrm{f}$ & & & & & & & & & & & & \\
\hline $\begin{array}{l}\text { build } \\
\text { customers' } \\
\text { awareness }\end{array}$ & $f x$ & 1920 & 1943 & 2520 & 1749 & 940 & 760 & 495 & 460 & & & & \\
\hline \multirow{2}{*}{$\begin{array}{l}\text { Offering } \\
\text { cheap and } \\
\text { attractive e- } \\
\text { banking } \\
\text { product }\end{array}$} & $f$ & 11 & 15 & 16 & 29 & 28 & 37 & 40 & 39 & \multirow[b]{2}{*}{205} & \multirow[b]{2}{*}{9278} & \multirow[b]{2}{*}{45.26} & \multirow[b]{2}{*}{7} \\
\hline & $f x$ & 800 & 1005 & 960 & 1537 & 1316 & 1480 & 1320 & 780 & & & & \\
\hline \multirow{2}{*}{$\begin{array}{l}\text { Development } \\
\text { of } \\
\text { infrastructure }\end{array}$} & $\mathrm{F}$ & 51 & 32 & 30 & 22 & 18 & 16 & 21 & 15 & \multirow[b]{2}{*}{205} & \multirow[b]{2}{*}{11669} & \multirow[b]{2}{*}{56.92} & \multirow[b]{2}{*}{1} \\
\hline & Fx & 4080 & 2144 & 1800 & 1166 & 846 & 640 & 693 & 300 & & & & \\
\hline \multirow{2}{*}{$\begin{array}{l}\text { Upgrading } \\
\text { technology }\end{array}$} & F & 23 & 27 & 44 & 35 & 26 & 30 & 13 & 07 & \multirow[b]{2}{*}{205} & \multirow[b]{2}{*}{11135} & \multirow[b]{2}{*}{54.32} & \multirow[b]{2}{*}{2} \\
\hline & $\mathrm{Fx}$ & 1840 & 1809 & 2640 & 1855 & 1222 & 1200 & 429 & 140 & & & & \\
\hline \multirow{2}{*}{$\begin{array}{l}\text { Innovative } \\
\text { initiative of } \\
\text { Bangladesh } \\
\text { bank }\end{array}$} & $\mathrm{F}$ & 20 & 17 & 26 & 30 & 39 & 29 & 28 & 16 & \multirow[b]{2}{*}{205} & \multirow[b]{2}{*}{10126} & \multirow[b]{2}{*}{49.40} & \multirow[b]{2}{*}{5} \\
\hline & FX & 1600 & 1139 & 1560 & 1590 & 1833 & 1160 & 924 & 320 & & & & \\
\hline \multirow{2}{*}{$\begin{array}{l}\text { Training bank } \\
\text { officials on } \\
\text { online } \\
\text { banking }\end{array}$} & $\mathrm{F}$ & 16 & 19 & 21 & 21 & 23 & 29 & 30 & 46 & \multirow[b]{2}{*}{205} & & & \\
\hline & Fx & 1280 & 1273 & 1260 & 1113 & 1081 & 1160 & 990 & 920 & & 9077 & 44.27 & 8 \\
\hline $\begin{array}{l}\text { Increasing } \\
\text { security }\end{array}$ & $\mathrm{F}$ & 37 & 41 & 16 & 24 & 14 & 22 & 23 & 28 & & & & \\
\hline
\end{tabular}




\begin{tabular}{|c|c|c|c|c|c|c|c|c|c|c|c|c|c|}
\hline measures & Fx & 2960 & 2747 & 960 & 1272 & 658 & 880 & 759 & 560 & 205 & 10796 & 52.66 & 3 \\
\hline \multirow{3}{*}{$\begin{array}{l}\text { Extension of } \\
\text { service across } \\
\text { the country }\end{array}$} & $\mathrm{F}$ & 23 & 25 & 10 & 11 & 37 & 23 & 35 & 41 & \multirow[b]{2}{*}{205} & \multirow[b]{2}{*}{9332} & \multirow[b]{2}{*}{45.52} & \multirow[b]{2}{*}{6} \\
\hline & $\mathrm{Fx}$ & 1840 & 1675 & 600 & 583 & 1739 & 920 & 1155 & 820 & & & & \\
\hline & & 80 & 67 & 60 & 53 & 47 & 40 & 33 & 20 & & & & \\
\hline
\end{tabular}

Source: Field survey

Customers perceived that the infrastructure of e-banking should be developed and placed at first position on the needed strategy (mean value 56.92) followed by upgrading technology with a mean value of 54.32. Commercial banks need to be updated with race of the innovative world and introduce new technology in rendering service. Besides the commercial banks, government has to take initiative to improve infrastructure including power supply. Customers have fear about the security of their fund, transaction, information. Thus they placed increasing security system in third position and expect that bank will take different measures to improve security system and customers' confident. Customers are not conscious about different e-banking service and feel doubt to receive innovative products. Customers perceived that banks should focus on building customers awareness by arranging several promotional campaign. Innovative initiative of Bangladesh bank and extension of service across the country are also considered as important strategy from the view point of customers. Still rural areas in Bangladesh are not under the shadow of modern banking service where a large portion of total population lives in village.

\section{CONCLUSION}

E-banking is now a global phenomenon. It is an invaluable and powerful tool driving development, supporting growth, promoting innovation and enhancing competitiveness Bangladesh has a good prospect of e-banking as the number of internet and modern technology users are increasing rapidly in the country. E-banking makes banking system easier, faster and accurate and extends banking service into a wide range. This paper assessed the customers' evaluation on the service quality of e-banking. This paper also studied the major challenges and required strategies for promoting e-banking in Bangladesh. There are a number of limitations which might influence the result of the study. The sample size of the study was not necessarily representative of the country's population as a whole as samples are taken from Chittagong district and ignored the other region of the country. The size of the sample is small. The research would have been more reliable if a greater size of sample had been used. It highly recommends future research to address all these concerns.

\section{REFERENCES}

Akber, S. M. \& Dey, A. (2020). Evaluation of the financial performance between traditional private commercial banks and Islamic banks in Bangladesh. International Journal of Islamic Banking and Finance Research, 4(2), 1-10. 
Ahmed, S.M.S., Rayhan,S.J., Islam, M.A., \& Mahjabin, S. (2012). Problems and prospects of mobile banking in Bangladesh. Journal of Arts, science \& commerce, 3(1), 47-58.

Al-Amin, S. \& Rahman, S. S. (2010). Application of electronic banking in Bangladesh. Bangladesh Research Publications Journal, 4(2), 172-184.

Alam, S., Khatibi, A., Santhapparaj, A. S., \& Talha, M. (2007). Development and prospects of internet banking in Bangladesh: Competitiveness review. An International Business Journal, 17(1/2), 56-66.

Baten, M. A., \& Kamil, A. A. (2010). E-banking of economical prospects in Bangladesh, Journal of Internet Banking and Commerce, 15(2), 1-10.

Bruene, J. (2002). Online banking by the numbers. Retrieved from www.onlinebankingreport.com

Burr, W. (1996). Wie informations technik die bank organisation verandern konnte, Bank mark, $11,28-31$.

Daniel, E. (1999). Provision of electronic banking in the UK and the Republic of Ireland. International Journal of Bank Marketing, 17(2), 25-34.

Halperin, K. (2001). Balancing Act, Company business and marketing, February.

Howcroft, B., Hamilton, R., \& Hewer, P. (2002). Consumer attitude and the usage and adoption of home based banking in the United Kingdom. Journal of Bank Marketing, 20(3), 111 121.

Huda, F., \& Chowdhury, T.A. (2017). Prospect of e-banking in Bangladesh: New way to make banking electronic, Asian Economic and Financial Review, 7(9), 509-518.

Khanam, Z., \& Alam, M.Z. (2018). Factors affecting the adoption of internet banking: A study on Dhaka city, Bangladesh. International Journal of Business and Innovation, 4(1), 0113

Liao, Z., \& Cheung, M.T. (2002). Internet-based e-banking and consumer attitudes: An empirical study. Information \& Management, 39, 283-295.

Masukujjaman, M., Siwar, C., Mahmud, M. R., \& Alam, S. S. (2016). Banker's perception of green banking: Learning from the experience of Islamic banks in Bangladesh. Malaysian Journal of Society and Space, 12(2), 144-153.

Mattila, A., \& Mattila, M. (2005). How perceived security appears in the commercialization of internet banking. Int. J. Financial Services Management, 3(1), 23-34. 
Mia, H., Rahman, M.A., \& Debnath, N. C. (2007).Consumer behavior of online banking in Bangladesh. Journal of Business Studies, 27(2), 151-181

Nasri, W. (2011). Factors influencing the adoption of internet banking in Tunisia. International Journal of Business and Management, 6(8), 143-160.

Nelubiri, O.N., \& Sinti, Q. (2006). Consumer's attitudes, systems characteristics and internet banking adoption in Malaysia. Management Research, 29(2), 16-27.

Sadekin, M.S., \& Shaikh, M.A.H. (2016). Effect of e-banking on banking sector of Bangladesh. International Journal of Economics, Finance and Management Sciences, 4(3), 93-97.

Sadekin, M.S., Mukta, S.N., \& Shaikh, M.A.H. (2019). Customers' trust on e-banking system in Bangladesh. International Journal of Economics, Finance and Management Sciences, 7(6), 178-186

Simpson, J. (2002). The impact of the internet in banking, observations and evidence from developed and emerging markets. Telematics and Informatics Journal, 19(4), 315-30.

Rahman. (2008). Innovative technology and bank profitability: The Bangladesh experience. Working paper series 0803, Bangladesh Bank, Retrieved from https://www.bb.org.bd/fnansys/bankfi.php, on December 15, 2008

Uddin, M.B., Haque, A., Rahman, M.M., \& Mamun, A.A.A. (2016). Electronic banking products and service of private commercial banks in Bangladesh: Present status and challenges. International Journal of Business and Management Review, 4(8), 44-55.

\author{
AUTHOR CONTRIBUTIONS \\ Conceptualization: Dhiman Barua, S. M. Akber \\ Data curation: Dhiman Barua, S. M. Akber \\ Formal analysis: Dhiman Barua, S. M. Akber \\ Funding Acquisition: Dhiman Barua, S. M. Akber \\ Project Administration: Dhiman Barua \\ Software: S. M. Akber \\ Validation: Dhiman Barua, S. M. Akber \\ Writing - Original Draft: Dhiman Barua, S. M. Akber \\ Writing - Review \& Editing: Dhiman Barua, S. M. Akber \\ CONFLICT OF INTEREST STATEMENT
}

The authors declare that they have no competing interests.

\title{
COPYRIGHTS
}

Copyright for this article is retained by the author(s), with first publication rights granted to the journal. This is an open-access article distributed under the terms and conditions of the Creative Commons Attribution license (https://creativecommons.org/licenses/by/4.0). 